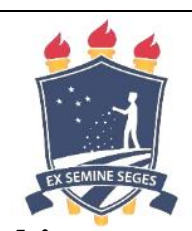

\title{
Lactoperoxidase enzyme activity and thiocyanate levels in raw milk of Girolando cows
}

\author{
[Atividade da enzima lactoperoxidase e teor de tiocianato no leite cru de vacas Girolando]
}

\section{"Scientific Article/Artigo Científico"}

\author{
Wandemberg Rocha Freitas ${ }^{1 *}$, Talita Camila Evaristo da Silva Nascimento ${ }^{2}$, Leandro Fragoso \\ Lins $^{2}$, Janaina de Lima Silva ${ }^{3}$, Keila Aparecida Moreira ${ }^{4}$, Ângela Maria Vieira Batista ${ }^{2}$, Severino \\ Benone Paes Barbosa ${ }^{2}$
}

\author{
${ }^{1}$ Federal Institute of Piauí - Campus Paulistana (IFPI), Paulistana-PI, Brazil. \\ ${ }^{2}$ Federal Rural University of Pernambuco (UFRPE), Recife-PE, Brazil. \\ ${ }^{3}$ Multidisciplinary Center of Barra, Federal University of the West of Bahia (UFOB), Barra-BA, Brazil. \\ ${ }^{4}$ Federal University of the Agreste of Pernambuco (UFAPE), Garanhuns-PE, Brazil. \\ ${ }^{*}$ Corresponding author/Autor para correspondência: E-mail: wandembergrocha@ hotmail.com
}

\begin{abstract}
Considering the importance of milk enzymes in milk preservation and animal protection, this study aimed to identify the factors that influence lactoperoxidase activity and levels of thiocyanate in raw milk of Girolando cows, as well as to verify the correlation between these components and the number of somatic cells in cooled raw milk. A total of 181 of milk samples from Girolando cows were used to determine the lactoperoxidase activity, thiocyanate levels, somatic cell number, and serum protein content. The genetic group and the sampling period influenced lactoperoxidase activity. Thiocyanate levels were influenced by the sampling period and by the interaction between the genetic group and the sampling period. The number of somatic cells was influenced by the number of days in lactation, animal age, and sampling period. Milk of animals from the group 1/2 Holstein x Gyr had the highest lactoperoxidase activity and there was no influence of the genetic group on the levels of thiocyanate.
\end{abstract}

Keywords: somatic cells; bovine milk; lactoperoxidase system.

\begin{abstract}
Resumo
Frente à importância das enzimas lácteas na conservação do leite e na proteção do animal, objetivou-se com esse estudo identificar os fatores que influenciam a atividade da enzima lactoperoxidase e os níveis de tiocianato no leite cru de vacas Girolando, bem como verificar a correlação entre esses componentes e o número de células somáticas no leite cru resfriado. Foram utilizadas um total de 181 amostras de leite de vacas Girolando para determinação da atividade da lactoperoxidase, teor de tiocianato, contagem de células somáticas e teor de proteínas do soro. Os fatores que influenciaram a atividade da lactoperoxidase foram o grupo genético e o período das amostras. O teor de tiocianato por sua vez foi influenciado pelo período das amostras e a interação grupo genético x período das amostras. O escore de células somáticas foi influenciado pelo número de dias em lactação, idade do animal e o período das amostras. O leite de animais 1/2 Holandês x Gir foi o que apresentou maior atividade da enzima lactoperoxidase e o teor de tiocianato não foi alterado pelo grupo genético dos animais.
\end{abstract}

Palavras-chave: células somáticas; leite bovino; sistema lactoperoxidase.

\section{Introduction}

Several studies have been carried out to determine the biological or physiological role of milk enzymes and the role of its several compounds, as well as to verify their relevance for milk quality and their influence on the technological processing and stability of dairy products (Andrews et al., 1991).

Bovine milk has more than 60 types of enzymes, among which, lactoperoxidase 
(EC.1.11.1.7) is an oxidase enzyme occurring naturally in milk. The combination of this enzyme with the thiocyanate ion and hydrogen peroxide results in the lactoperoxidase system (LPS), which generates hypothiocyanite ions and has antibacterial activity in milk (Al-Baarri et al., 2012).

The LPS is a non-specific protection mechanism of the mammary gland, found in all mammal species, and comprises a series of chemical reactions, for which the presence of thiocyanate and hydrogen peroxide is indispensable to active the lactoperoxidase enzyme (Sermon et al., 2005).

Milk, mammary gland and gastrointestinal tract protection of calves against pathogenic microorganisms are the lactoperoxidase enzyme's main biological roles. (Kussendrager and Van Hooijdonk, 2000; Seifu et al., 2005; Boots and Floris, 2006; Atasever et al., 2013).

Due to the importance of milk enzymes in milk preservation and animal protection, it is fundamental to evaluate the factors that may alter its activity. According to Calamari et al. (2005), milk enzyme activity may be influenced by several factors, including breed, animal age, diet, nutritional status, number of lactations, lactation stage, mammary gland health, and seasonal variations.

Thus, this study aimed to identify the factors that influence lactoperoxidase activity and the levels of thiocyanate in raw milk of Girolando of the genetic groups $1 / 2,3 / 4$ and $7 / 8$ Holstein $x$ $\mathrm{Gyr}(\mathrm{HG})$, as well as to evaluate the correlation of these components with the number of somatic cells in cooled raw milk.

\section{Material and Methods}

A total of 181 samples, together with their origin information (genetic group, age, lactation, sampling period, and management), from the dairy control of a single property, were donated by the Laboratory of the Dairy Herd Management Program of the Northeast region of Brazil (PROGENE Laboratory). This laboratory is linked to the Department of Zootechny / Animal Science of the Federal Rural University of Pernambuco and associated with the Brazilian Network of Milk Quality Analysis Laboratories (RBQL).

Samples of raw milk from Girolando cows of the genetic groups $1 / 2,3 / 4$ and $7 / 8 \mathrm{HG}$ were used. These animals were 29 to 140 months of age and were between 14 to 369 days in lactation, from two different periods: August to September $\left(1^{\text {st }}\right.$ period $)$ and December $\left(2^{\text {nd }}\right.$ period $)$, with stable management conditions.

The samples were conditioned in isothermal boxes (around $4^{\circ} \mathrm{C}$ ) and analyzed in up to 24 hours. An aliquot of $40 \mathrm{~mL}$ of milk was used to determine lactoperoxidase activity and thiocyanate levels. Another aliquot of $40 \mathrm{~mL}$ of milk containing Bronopol $^{\circledR}$ preservative (2bromo-2-nitro-1,3-propanediol) (D and F Control System Inc., U.S.A.) was used in the somatic cell count (SCC) and to determine the serum protein content obtained by the difference between the total protein and casein contents.

Lactoperoxidase activity was determined according to the method described by Kumar and Bhatia (1999), and was defined as the amount of enzyme that catalyzed the oxidation of $1 \mu \mathrm{mol}$ of 2,2'-azino-bis (3- ethylbenzothiazoline-6-sulfonic acid) diammonium salt (ABTS) (Sigma-Aldrich Inc., U.S.A.) per minute at room temperature (20 $\pm 2^{\circ} \mathrm{C}$ ).

The thiocyanate quantification was performed according to the Codex Alimentarius Commission (CAC, 1991), using the Biochrom ${ }^{\circledR}$ Libra S22 UV/Vis spectrophotometer (Biochrom Ltd., United Kingdom), and the calibration curve was obtained using potassium thiocyanate P.A. as a standard.

Total protein and casein contents were determined by spectrometric analysis, in the medium-infrared, Bentley 2000 ${ }^{\circledR}$ (Bentley Instruments Inc., U.S.A.), and the results were expressed as $\mathrm{g} / 100 \mathrm{~g}$ of milk.

Somatic cell count was performed using a Somacount $300^{\circledR}$ (Bentley Instruments Inc., U.S.A.), which operates according to the flow cytometry principle; the results were expressed as somatic cell units per $\mathrm{mL}$ of milk. The results from this analysis were transformed into somatic cell score (SCS) (Shook and Schutz, 1994) because the data had no normal distribution, given by the following equation:

\section{(1) $\mathrm{SCS}=\log _{2}(\mathrm{SCC}$ por $\mu \mathrm{l} / 100)+3$}

Four classes of production levels were formed (Table 1), according to the provided origin information, in order to verify the influence of the level of milk production on the response variables.

The variables that influenced lactoperoxidase activity (model 1), thiocyanate levels (model 2), and somatic cell score (model 3) 
were subjected to analysis of variance, according to the models described below:

$$
\begin{gathered}
\text { (1) } \hat{Y}_{i j k l m n o p}=\mu+T_{i}+P S_{j}+I_{k}+D E L_{l}+E C S_{m}+ \\
G G_{n}+N P_{o}+P C_{p}+(G G-N P)_{n o}+(G G-P C)_{n p}+ \\
\varepsilon_{i j k l m n o p}
\end{gathered}
$$

Where, $\hat{Y}_{i j k l m n o p}=$ lactoperoxidase activity ( $\left.\mathrm{U} \mathrm{mL}^{-1}\right), \mu=$ constant common to all observations, $T_{i}=$ linear regression coefficient of the thiocyanate level effect $\left(\mathrm{mgL}^{-1}\right), P S_{j}=$ linear regression coefficient of the serum protein content

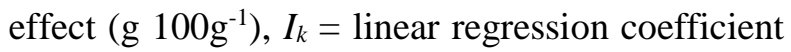
of the animal age effect (months), DIL $L_{l}=$ linear regression coefficient of the effect of the number of days in lactation, $S C S_{m}=$ linear regression coefficient of the effect of the somatic cell score, $G G_{n}=$ n-th genetic group effect (n $=1 / 2,3 / 4$ or $7 / 8 \mathrm{HG}), N P_{o}=0$-th animal production level $(\mathrm{o}=$ $1,2,3$ or 4$), P C_{p}=\mathrm{p}$-th sampling period $(\mathrm{p}=1$ : August - September, 2: December), $(G G-N P)_{n o}$ $=$ effect of the interaction between genetic group and production level, $(G G-P C)_{n p}=$ effect of the interaction between genetic group and sampling period, $\varepsilon_{i j k l m n o p}=$ error associated with the observation with $N(0 ; \sigma 2 \varepsilon)$ distribution.

$$
\begin{gathered}
\text { (2) } \hat{Y}_{i j k l m n o}=\mu+P S_{i}+I_{j}+D E L_{k}+E C S_{l} \\
+G G_{m}+N P_{n}+P C_{o}+(G G-N P)_{m n}+(G G- \\
P C)_{m o}+\varepsilon_{i j k l m n o}
\end{gathered}
$$

Where, $\hat{Y}_{i j k l m n o}=$ thiocyanate levels $\left(\mathrm{mgL}^{-1}\right)$, $\mu=$ constant common to all observations, $P S_{i}=$ linear regression coefficient of the serum protein content effect $\left(\mathrm{g} 100 \mathrm{~g}^{-1}\right), I_{j}=$ linear regression coefficient of the animal age effect (months), $D I L_{k}$ $=$ linear regression coefficient of the effect of the number of days in lactation, $S C S_{l}=$ linear regression coefficient of the effect of the somatic cell score, $G G_{m}=\mathrm{m}$-th genetic group effect ( $\mathrm{n}=$ $1 / 2,3 / 4$ or $7 / 8 \mathrm{HG}), N P_{n}=$ n-th animal production level (o $=1,2,3$ or 4$), P C_{o}=$ o-th sampling period (o = 1: August - September, 2: December), (GG$N P)_{m n}=$ effect of the interaction between genetic group and production level, $(G G-P C)_{m o}=$ effect of the interaction between genetic group and sampling period, $\mathcal{E}_{i j k l m n o}=$ error associated with the observation with $N(0 ; \sigma 2 \varepsilon)$ distribution.

(3) $\hat{Y}_{i j k l m}=\mu+I_{i}+D E L_{j}+G G_{k}+N P_{l}+P C_{m}+$ $(G G-N P)_{k l}+(G G-P C)_{k m}+\varepsilon_{i j k l m}$
Table 1. Distribution of classes according to the daily milk production level.

\begin{tabular}{cc}
\hline Classes & Milk (kg/day) \\
\hline 1 & $>5 \leq 10$ \\
2 & $>10 \leq 15$ \\
3 & $>15 \leq 20$ \\
4 & $>20$ \\
\hline
\end{tabular}

Where, $\hat{Y}_{i j k l m}=$ somatic cell score, $\mu=$ constant common to all observations, $I_{i}=$ linear regression coefficient of the animal age effect (months), $D I L_{j}=$ linear regression coefficient of the effect of the number of days in lactation, $G G_{k}$ $=\mathrm{k}$-th genetic group effect, $(\mathrm{n}=1 / 2,3 / 4$ or $7 / 8$ $\mathrm{HG}), N P_{l}=1$-th animal production level $(1=1,2$, 3 or 4$), P C_{m}=\mathrm{m}$-th sampling period $(\mathrm{m}=1$ : August - September, 2: December), $(G G-N P)_{k l}$ $=$ effect of the interaction between genetic group and production level, $(G G-P C)_{k m}=$ effect of the interaction between genetic group and sampling period, $\varepsilon_{i j k l m}=$ error associated with the observation with $N(0 ; \sigma 2 \varepsilon)$ distribution.

Pearson's correlation analysis was performed between the lactoperoxidase activity ( $\left.\mathrm{U} \mathrm{mL} \mathrm{m}^{-1}\right)$, thiocyanate levels $\left(\mathrm{mgL}^{-1}\right)$, serum proteins $\left(\mathrm{g} 100 \mathrm{~g}^{-1}\right)$, and somatic cell score (log cells $\left.\mathrm{mL}^{-1}\right)$.

Statistical analysis was carried out using the SAS (Statistical Analysis System) statistical package, version 9.0. The means were compared by the Tukey's test, adopting 0.05 as a critical level of probability for Type I error.

\section{Results and Discussion}

For lactoperoxidase activity, a mean value of $10.53 \mathrm{U} \mathrm{mL}^{-1}( \pm 6.81)$ was found, with a minimum activity of $1.25 \mathrm{U} \mathrm{mL}^{-1}$ and a maximum of $51.17 \mathrm{U} \mathrm{mL}^{-1}$. For the levels of thiocyanate, the mean value was $14.67 \mathrm{mgL}^{-1}( \pm 10.48)$, with minimum and maximum values of $2.90 \mathrm{mgL}^{-1}$ and $48.89 \mathrm{mgL}^{-1}$, respectively. The mean values for somatic cell score (SCS) and somatic cell count (SCC) were $4.82( \pm 1.98)$ cells $/ \mathrm{mL}$ and $8.39 \times 10^{5}$ cells $/ \mathrm{mL}\left( \pm 1.52 \times 10^{6}\right)$, respectively.

The mean activity of the lactoperoxidase found in this study was higher than those observed in studies carried out with Holstein cows in Iran (Asadpour et al., 2008) and in Italy (Calamari et al., 2005). The lactoperoxidase activity had a high variation when comparing the samples, corroborating the results found by Seifu et al. (2007), Lujerdean and Buena (2010), and Yaqub et al. (2012). 
The thiocyanate levels obtained in this study were higher than those found by Fweja et al. (2007) in milk of Ayrshire and Tanzania Short Horn Zebu cows, and by Ponce (2012) in animals of a rustic breed in Cuba, Venezuela, and Mexico. The thiocyanate levels also varied between the groups, corroborating the results found by Ponce et al. (1998), Fonteh et al. (2002), Seifu et al. (2007), and Yaqub et al. (2012).

Lactoperoxidase activity was influenced $(\mathrm{P}<0.05)$ by the genetic group (Table 2), indicating differences according to the genetic proportion of each of the breeds. The $1 / 2 \mathrm{HG}$ samples showed higher enzymatic activity, differing $(\mathrm{P}<0.05)$ from the other two groups $(3 / 4$ and $7 / 8 \mathrm{HG}$ ). This can be explained by the higher SCS in the milk of $1 / 2 \mathrm{HG}$ cows, which probably contributed to a higher enzymatic activity, and/or due to the heterosis that may manifest in a more pronounced way in these animals in comparison with the other genetic groups studied, causing them to present a higher immunological activity.

The sampling period also influenced $(\mathrm{P}<0.01)$ the lactoperoxidase activity and the thiocyanate levels (Table 2). The SCS was higher in milk from the 1st sampling period in all genetic groups (Table 2), which may explain the higher enzymatic activity in this period. Calamari et al. (2005) observed an effect of the different seasons of the year on the lactoperoxidase activity in Holstein cows' milk. Seasonal changes are usually associated with changes in diets; however, this possibility can be discounted because lactoperoxidase activity is not essentially affected by the animals' diet (Fweja et al., 2007).

Table 2. Mean values adjusted to the lactoperoxidase activity $\left(\mathrm{U} \cdot \mathrm{mL}^{-1}\right)$, thiocyanate levels $\left(\mathrm{mgL}^{-1}\right)$ and somatic cell score $\left(\log\right.$ cells $\left.\mathrm{mL}^{-1}\right)$ per genetic group and sampling period.

\begin{tabular}{ccccc}
\hline \multicolumn{2}{c}{ Sources of variation } & Lactoperoxidase & Thiocyanate & Somatic cell score \\
\hline \multirow{2}{*}{ Genetic group } & $1 / 2 \mathrm{HG}$ & $14,661^{\mathrm{a}}$ & $16,518^{\mathrm{a}}$ & $5,217^{\mathrm{a}}$ \\
(Holstein x Gyr) & $3 / 4 \mathrm{HG}$ & $8,340^{\mathrm{b}}$ & $13,599^{\mathrm{a}}$ & $4,772^{\mathrm{ab}}$ \\
& $7 / 8 \mathrm{HG}$ & $8,106^{\mathrm{b}}$ & $13,436^{\mathrm{a}}$ & $4,438^{\mathrm{b}}$ \\
\hline \multirow{2}{*}{ Sampling period } & 1st (Aug-Sep.) & $12,060^{\mathrm{a}}$ & $18,741^{\mathrm{a}}$ & $5,185^{\mathrm{a}}$ \\
& 2nd (Dec.) & $8,715^{\mathrm{b}}$ & $9,945^{\mathrm{b}}$ & $4,392^{\mathrm{b}}$ \\
\hline
\end{tabular}

Note: Means in the same column followed by different letters are significantly different by Tukey's test at $5 \%$ probability level.

In addition, there was no effect $(\mathrm{P}>0.05)$ of the thiocyanate, serum proteins, animal age, days in lactation, production level, and somatic cell score on lactoperoxidase activity.

Thiocyanate had a mean concentration of $14.67 \mathrm{mgL}^{-1}$, which was very close to the value (14.50 $\mathrm{mgL}^{-1}$ ) reported by Ponce (2012), indicating that the milk analyzed in our study had an optimum quantity of ions for the lactoperoxidase system activation.

Serum proteins did not affect the lactoperoxidase activity. This variable could be relevant because the lactoperoxidase is a milk serum protein; however, no change was observed.

Contrary to the present study, Asadpour et al. (2008) found an effect of cow's age on lactoperoxidase activity, when studying Holstein cows from first to third orders of delivery at the beginning of lactation.

Regarding the number of days in lactation, Althaus et al. (2001), Fonteh et al. (2002), Lujerdean and Buena (2010), and Yaqub et al. (2012), studying milk of sheep, goat, cow and buffalo, respectively, found a cyclic variation in lactoperoxidase activity, with increases during lactation and subsequent reduction. The production level, although it has had no influence on the lactoperoxidase activity, could alter milk composition because the content of each milk components is not necessarily related to the increase or decrease in the volume of milk produced. However, Yaqub et al. (2012) found no association between lactoperoxidase activity and milk production.

Different from the results obtained in our study, in which the SCS had no influence on the lactoperoxidase activity, Seifu et al. (2007) and Isobe et al. (2011) found a higher enzymatic activity in the milk of Holstein cows and a higher number of somatic cells in the milk of Saanen goats. Probably, after transforming the values into score, the difference between the genetic groups was not detected due to the proximity of the values, since a higher number of somatic cells may increase the enzyme activity because it is produced by immune system cells.

Interactions between genetic group and production level and between the genetic group and sampling period had no influence $(\mathrm{P}>0.05)$ on lactoperoxidase activity. 
Like lactoperoxidase activity, thiocyanate levels were not affected $(\mathrm{P}>0.05)$ by SCS (Table 2). Thus, milk samples evaluated in this study may be considered from a healthy herd, with a low incidence of mastitis because, according to Ponce (2012), the higher the mastitis index in the herd, the higher the thiocyanate levels in the milk. This may be related to the increase in the mammary tissue permeability and consequently to a higher intensity in the flow of ions by the osmotic pressure difference between blood and milk.
The sampling period influenced $(\mathrm{P}<0.01)$ the thiocyanate levels in milk of Girolando cows (Table 3). Similar to the lactoperoxidase activity, samples from the first period had the highest concentration of thiocyanate, which may be related to the higher number of somatic cells observed in this period. In the case of milk from healthy cows, the high levels of thiocyanate are due to the diet of the animals, more precisely because of the food containing cyanogenic glycosides, which contribute significantly to the production of this ion (Korhonen, 1980).

Table 3. Adjusted mean values for thiocyanate levels $\left(\mathrm{mgL}^{-1}\right)$ per genetic group and sampling period.

\begin{tabular}{ccccc}
\hline \multicolumn{2}{c}{ Sources of variation } & \multicolumn{3}{c}{ Genetic group (Holstein x Gyr) } \\
\cline { 3 - 5 } & & $1 / 2 \mathrm{HG}$ & $3 / 4 \mathrm{HG}$ & $7 / 8 \mathrm{HG}$ \\
\hline \multirow{2}{*}{ Sampling period } & 1st (Aug-Sep.) & $23,2^{\mathrm{aA}}$ & $15,8^{\mathrm{bA}}$ & $16,6^{\mathrm{bA}}$ \\
& 2nd (Dec.) & $9,86^{\mathrm{aB}}$ & $11,3^{\mathrm{aA}}$ & $10,2^{\mathrm{aB}}$ \\
\hline
\end{tabular}

Note: Means in the same column followed by different uppercase letters and means in the same row followed by different lowercase letters are significantly different by Tukey's test at $5 \%$ probability.

A rainy second sampling period was expected, according to the characteristics of the region; however, between the first and second period, precipitation was equal to zero; therefore, the second period was drier than the first one. Despite this fact, food and water supply was constant during the sampling periods, according to information provided. Nevertheless, probably part of the difference in thiocyanate levels may be attributed to the feed used in the two seasons (1st and 2 nd period), mainly regarding the pasture (2nd period in the driest season).

In Italy, Calamari et al. (2005) found different thiocyanate levels in milk of Holstein cows collected in different seasons (lower values in the summer and higher values in the winter), even supplying the animal the same kind of feed, with small variations in the quantity of each ingredient, during the whole period.

The interaction between the genetic group and sampling period $(\mathrm{P}<0.05)$ influenced the levels of thiocyanate between the genetic groups in the different sampling periods. Milk from group $1 / 2 \mathrm{HG}$, in the 1st sampling period, had the highest levels of thiocyanate, during the whole experimental period (Table 3), reinforcing the somatic cell influence on the lactoperoxidase system, even though the feed has been responsible for part of the concentration of this ion.

Serum proteins, animal age, number of days in lactation, genetic group, production level, and interactions had no influence $(\mathrm{P}>0.05)$ on thiocyanate levels. Despite the absence of age effect, there was a trend of increase in the levels of thiocyanate in samples from older animals. This is possible because of the natural resistance mechanisms of the mammary gland since according to Ponce et al. (1998), there is a nonspecific defense activity of the lactoperoxidase system.

The SCS was influenced $(\mathrm{P}<0.01)$ by the number of days in lactation and by the sampling period. There was an increase $(\mathrm{P}<0.05)$ in SCS (Figure 1) with the increase in the number of days in lactation. It is natural that the samples from animals subjected to a longer period of lactation have a higher number of somatic cells per $\mathrm{mL}$ of milk, since the reduction in the volume produced results in a higher concentration of compounds, as well as in an increase in the number of cells from the alveolar tissue desquamation in the milk.

Regarding the sampling period, the differences in SCS can be observed in Table 2. The fact that the 2 nd period samples were from a drier season than those from the 1 st period possibly influenced the number of somatic cells, reducing the number of animals with mastitis. In the dry season, the occurrence of environmental mastitis becomes less frequent as the environment has lower humidity. Calamari et al. (2005) also observed a reduction in SCS in milk during the summer.

Animal age, genetic group, production level, and the interactions between genetic group and production level and between the genetic group and sampling period had no influence on 
the SCS, suggesting that this variable is more affected by environmental factors.

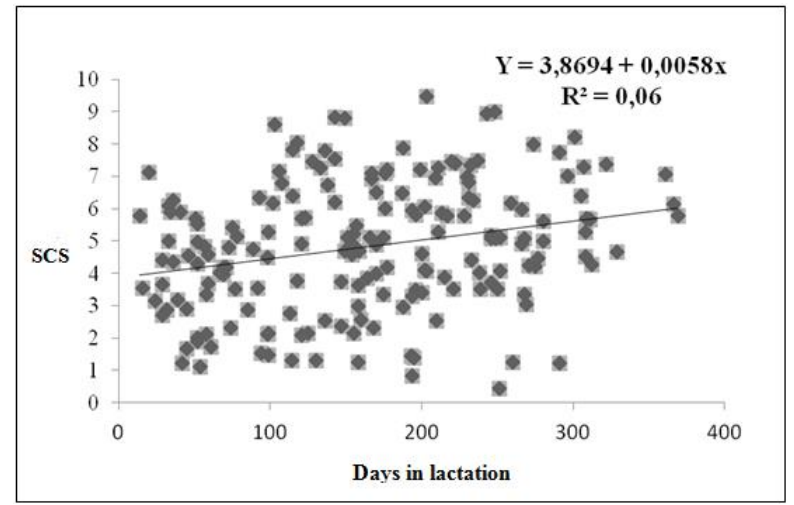

Figure 1. Observed and predicted behavior for somatic cell score (SCS) as a function of the number of days in lactation in Girolando cows.

The correlation analysis showed positive associations $(\mathrm{P}<0.05)$ between the levels of thiocyanate and SCS $(r=0.30)$ and between the level of thiocyanate and serum proteins $(r=0.25)$, indicating that the increase in one variable will cause an increase in the other. Regarding lactoperoxidase, there was no correlation $(\mathrm{P}>0.05)$ between the variables studied, corroborating the results obtained by Fonteh et al. (2002), Fweja et al. (2007), and Asadpour et al. (2008). Seifu et al. (2007), studying goat milk, found a high correlation between lactoperoxidase and somatic cells; however, found no correlation either between lactoperoxidase and thiocyanate or between SCS and thiocyanate.

\section{Conclusion}

It is concluded that the genetic group and sampling period influence the lactoperoxidase activity, with higher enzymatic activity in cooled raw milk of Girolando cows from the genetic group 1/2 Holstein x Gyr. The thiocyanate levels are influenced by the sampling period and by the interaction between the genetic group and the sampling period. In cooled raw milk of Girolando cows from the genetic groups $1 / 2,3 / 4$ and $7 / 8$ Holstein $\mathrm{x}$ Gyr, there is no correlation of lactoperoxidase and thiocyanate levels with the number of somatic cells.

\section{Conflict of Interests}

The authors declare that there is no conflict of interest.

\section{Ethics Committee}

The authors declare that there are no ethical objections once the milk samples and their origin information were donated by the Laboratory of the Dairy Herd Management Program of the Northeast region of Brazil (PROGENE Laboratory). Furthermore, there was not any intervention on the animals.

\section{Acknowledgements}

The authors would like to thankful CAPES and Federal Rural University of Pernambuco for their financial support.

\section{References}

Al-Baarri, A.N.; Ogawa, M.; Visalsok, T.; Hayakawa, S. Lactoperoxidase immobilized onto various beads for producing natural preservatives solution. Journal of Applied Food Technology, 1(1): 4-6, 2012.

Althaus, R.L.; Molina, M.P.; Rodríguez, M.; Fernández, N. Analysis time and lactation stage influence on lactoperoxidase system components in dairy ewe milk. Journal of Dairy Science, 84(8): 1829-1835, 2001.

Andrews, A.T.; Olivecrona, T.; BegtssonOlivecrona, G.; Fox, P.F.; Bjorck, L.; Farkye, N.Y. Indigenous enzymes in milk. In: Fox, P.F. Food Enzymology. $1^{\text {st }}$ ed. London: Elsevier, 1991. p.53-129.

Asadpour, R.; Tayefi-Nasrabadi, H.; Moghadam, G.A.; Nofouzi, K. Correlation between lactoperoxidase activity and somatic cell count for diagnosis subclinical mastitis in early lactation of dairy cows. Journal of Animal and Veterinary Advances, 7(7): 777-779, 2008.

Atasever, A.; Ozdemir, H.; Gulcin, I.; Kufrevioglu, O.I. One-step purification of lactoperoxidase from bovine milk by affinity chromatography. Food Chemistry, 136: 864870, 2013.

Boots, J.W.; Floris, R. Lactoperoxidase: from catalytic mechanism to practical applications. International Dairy Journal, 16: 1272-1276, 2006.

CAC. Codex Alimentarius Commission. Guidelines for the preservation of raw milk by use of the lactoperoxidase system, CAC/GL 13-1991, 1991. Available at: <www.fao.org/input/download/standards/29/C XG_013e.pdf>. Accessed on: $01 \operatorname{dec} 2018$. 
Calamari, L.; Maianti, M.G.; Bani, P.; Sarti, L. Seasonal variations of some enzyme activities of cow milk. Italian Journal of Animal Science, 4: 212-214, 2005.

Fonteh, F.A.; Grandison, A.S.; Lewis, M.J. Variations of lactoperoxidase activity and thiocyanate content in cows and goats milk throughout lactation. Journal of Dairy Research, 69: 401-409, 2002.

Fweja, L.W.; Lewis, M.J.; Grandison, A.S. Alternative strategies for activation of the natural lactoperoxidase system in cows' milk: trials in Tanzania. Journal of Dairy Research, 74(4): 381-386, 2007.

Isobe, N.; Kubota, H.; Yamasaki, A.; Yoshimura, Y. Lactoperoxidase activity in milk is correlated with somatic cell count in dairy cows. Journal of Dairy Science, 94(8): 38683874, 2011.

Korhonen, H. A new method for preserving milk the lactoperoxidase antibacterial system. World Animal Review, 35: 23-29, 1980.

Kumar, R.; Bhatia, K.L. Standardization of method for lactoperoxidase assay in milk. Lait, 79(2): 269-274, 1999.

Kussendrager, K.D.; Van Hooijdonk, A.C.M. Lactoperoxidase: physico-chemical properties, occurence, mechanism of action and application. British Journal of Nutrition, 84: S19-S25, 2000.

Lujerdean, A.; Bunea, A. The influence of lactation stage on lactoperoxidase activity. Animal Science and Biotechnologies, 67(12): 231-234, 2010.

Ponce, P.; Alfonso, H.A.; Diaz, B.; Capdevila, J.; Yanez, J. Factores asociados al contenido de tiocianato en leche cruda. Revista de Salud Animal, 76: 96-99, 1998.

Ponce, P. Thiocyanate content in raw milk under the American tropic conditions in relation to the activation of the lactoperoxidase system. Revista de Salud Animal, 34(2): 115-119, 2012.

Seifu, E.; Buys, E.M.; Donkin, E.F. Significance of lactoperoxidase system in the dairy industry and its potential applications: a review. Food Science and Technology, 16: 137-157, 2005.

Seifu, E.; Donkin, E.F.; Buys, E.M. Potential of lactoperoxidase to diagnose subclinical mastitis in goats. Small Ruminant Research, 69: 154-158, 2007.

Sermon, J.; Vanoirbeek, K.; Spiegeleer, P. de.; Van Houdt, R.; Aertsen, A.; Michiels, C.W. Unique stress response to the lactoperoxidasethiocyanate enzyme system in Escherichia coli. Reseach in Microbiolology, 156(2): 225232, 2005.

Shook, G.E.; Schutz, M.M. Selection on somatic cell score to improve resistance to mastitis in the United States. Journal of Dairy Science, 77: 648-658, 1994.

Yaqub, T.; Sadaf, S.; Mukhtar, N.; Zaneb, H.; Shabbir, M.Z.; Ahmad, A.; Aslam, A.; Ashraf, K.; Ahmad, N.; Rehman, H. The influence of time elapsed after milking and lactation stage on the lactoperoxidase system of milk in Sahiwal cattle and Nili-Ravi buffaloes. International Journal of Dairy Technology, 65(3): 360-364, 2012. 